\title{
Interaction in Online Learning \\ Environment during Covid -19: Factors behind Lack of Interaction and Ideas for Promoting it
}

\author{
Mohammed A. A. Farrah \\ English Department, Faculty of Arts, Hebron University, Palestine \\ mfarrah@hebron.edu \\ Shatha "Mohammad Ghassan" Jabari \\ English Department, Faculty of Arts, Hebron University, Palestine \\ Shathaagj@gmail.com
}




\title{
Interaction in Online Learning Environment during Covid -19: Factors behind Lack of Interaction and Ideas for Promoting it
}

\author{
Mohammed A. A. Farrah"a, Shath "Mohammad Ghassan" Jabarib \\ a English Department, Faculty of Arts, Hebron University, Palestine \\ ${ }^{b}$ English Department, Faculty of Arts, Hebron University, Palestine \\ E-mails: amfarrah@hebron.edu, bShathaagj@gmail.com
}

\begin{abstract}
Due to COVID-19 pandemic, the learning process shifted from face- to- face learning into online learning as schools and universities closed almost all over the word. With the shift from face to face into online learning, the learning process effected negatively specially students' interaction. In the online learning process, students tend to avoid interacting for many different reasons the study discussed. In light of this shift, by exploring the experiences and perceptions of the English language students at Hebron University, Palestine, this descriptive survey research aimed to investigate the reasons behind students' lack of interaction during their online class sessions. It also tries to provide some useful ideas and suggestion that instructors may use in order to increase their students' interaction and participation with relevance to some other studies. The researchers employed a mono method quantitative research approach. A survey-questionnaire was posted online through Google forms to all English language major students Hebron University. The findings reported some reasons behind lack of interaction and some suggestions to promote interaction based on the participants' perceptions. The study provides instructors and educational decision makers with pedagogical insights that may better shape the learning/teaching process in the online environment.
\end{abstract}

Keywords: COVID-19; interaction, online learning; face to face learning; participation; ideas and suggestions.

\section{Introduction}

Interaction is considered as an integral part in the learning process and it is important for both students and teachers as it make learning more effective as well as productive as Evans (2020) said "Interaction is what is making this learning visible and, therefore, effective". Interaction in the learning process is divided into three main types and these types are: among the students interaction, students-teachers interaction, content-students interaction. The first type is among students interaction is the interaction that happens between the students who take a course. This interaction can be between individuals, groups, whole class students. This type of interaction focuses on how students communicate with each other and how this communication is effective. The learning environment that allows students to communicate and interact with each other is considered an affective environment as it helps them to construct their knowledge and it promotes collaborative and cooperative work so they share their knowledge with each other, help each other to overcome learning difficulties, and help each other in understanding the materials. A project that had been done in 2011 by Reformed Teaching Observation Protocol (RTOP) observers showed that:

"Classes that have low interaction among students are more lecture-focused, often well-organized, and tend to present material clearly, with minimal text and wellchosen images. The instructor is usually well-versed in the content, but teaches in a way that does not provide an opportunity for interactions among students. In contrast, a more student-focused class provides multiple opportunities for students to discuss ideas in small groups and may support a whole class discussion."(para 2)

${ }^{*}$ Corresponding author

Email address: mfarrah@hebron.edu (Mohammed A. A. Farrah)

DOI: https://doi.org/10.31559/BAES2020.5.2.3 
The second type is students and teachers interaction. Students-teacher interaction in the classroom plays a crucial part in the learning process as it makes learning affective. Krause, Bochner and Duchesne (2006) defined interaction between students and teachers as a shared acceptance, understanding, intimacy, trust, affection, and so on. A good and positive relationship between students and teachers promotes the academic success in students. Actually, the students who have a good relationship with their teachers perform much better than the students who did not. According to Che Ahmad, Shaharim and Abdullah, (2017), teachers-students interaction creates a good atmosphere and good relationships in the classroom and contributes to the learning effectiveness. The last type is the interaction between the student and the content of the course. This type of interaction is equally important to the other types as Moore (1989) said that this type of interaction is a defining aspect in the leaning process. Varisada (2000) stated that "student- content interaction is fundamental type of interaction that the whole education is based on". The success of the education process and learning depends profoundly on the positive students-content interaction. Students who do not have a positive interaction with the content and the course material do not success in their education because students and content are essential elements in the learning process. Richards and Rodgers (2004) stated that teachers and learners are both accountable for promoting classroom interaction in TBLT.

Recently, and due to the Corona Virus Pandemic, education has shifted from face-to face learning to online learning as schools and universities closed. The COVID-19 has resulted in closing most schools around the world and according to some statistics there are over 1.2 milion children out from classrooms. Li and Lalani (2020) stated that "as result of this pandemic, the online learning rates have raised and teaching is now undertaking remotely and on digital platforms". Online learning is totally different from face to face learning and, of course, much harder for both teachers and students. This kind of leaning is done via internet, educational applications, and digital platforms where teachers and students do not meet in class but online. Online learning has some advantages such as saving time, saving health, reduces the expenses, and available for all students. Beside the disadvantages online leaning have such as internet connection problems, the need for technological skills, cheating problems, and so on, and the main disadvantage for the online learning is the reduction and the lack of participation and interaction between students, teachers, and content.

Castaneda and Rentz (2020) stated that teachers and educators do not engage students in the classroom discussions and do not allow students to interact with each other and with course materials. Baber (2021) has found that social interaction has a great impact on the successfulness and the effectiveness of the online learning. The effectiveness of the social interaction is, unfortunately, reduced because most students and people focus on continuing the learning and saving their lives rather than socializing in the online environment.

The reasons behind the reduction of interaction and participation in the online learning are as follows:

- Some students do not have the self-confidence to talk and participate in the online courses and lectures.

- Some students have bad internet connections and sometimes they don't have internet connection.

- Some students do not attend the online lectures at all and depend on the recording.

- Some students do not have the needed devices to access the courses such as smart phones, laptops, iPad, and so on

- Some teachers do not allow students to participate.

- Some teachers do not have technological skills.

There are much more reasons behind the lack of participation. A study by Dewitt (2020) showed that most students live in homes that may not have access to internet or may have a limited access as they also do not have devices to use for the schoolwork. He also found that most students do not find the incentives to attend classes such as grades incentives, so they do not attend classes which as a result will reduce the participation rates.

\subsection{Statement of the problem}

Before Covid 19 outburst, some educational institutions were using partially blended learning classes just to assist the process of language learning (Itmeizeh, \& Farrah, 2021; Vellanki, \& Bandu, 2021; Benadla, \& Hadji, 2021; Zboun, \& Farrah, 2021; Dhawan, 2020; Farrah \& Al-Bakri, 2020; Abu Safiyeh, \& Farrah, 2020). The shift from face-to-face learning into online learning has affected the learning process in general and students' interaction specifically. Many scholars expressed their concern that the lack of interaction (Claudiu et al. 2020). Students' interaction in online learning had been reduced and most students avoid interacting during their online classes while interaction is an important element in the learning process (Vellanki, \& Bandu, 2021; Benadla, \& Hadji, 2021). Some students do not interact during their online classes for many reasons. This poses a real problem for online learning. Consequently, to improve the nature of interaction outcome, online educators should carefully use the most helpful techniques that promote meaningful interaction, the one which motivates their students and helps improve the learning/teaching process in the online environment. Thus, it follows that there is a necessity to explore some ideas and suggestion that promote interaction in the EFL classroom.

\subsection{The purpose of the study}

This paper is concerned with the students' interaction during the online courses and it aims to investigate the ideas that may enhance students' participation and interaction during online courses by providing some useful and helpful suggestions and idea that can promote student's interaction in online learning. 


\subsection{Research Question \\ This study addresses two research questions: \\ - What are the reasons behind students' lack of interaction during online courses? \\ - How can we enhance students' interaction during online courses?}

\subsection{Significance of the study}

As delivering fully online classes started in most education institutions after the outbreak of Covid, 19 , there is a dearth of research conducted on the nature of interaction in the online environment. Most of the studies that were conducted before Covid 19 outbreak were partially online classes (Phipps \& Merisotis, 2000; Little, 2000; Kearsley, 2000; Ho, 2004; Kelsey \& D'souza 2004; Farrah, 2006). In the above mentioned studies, online learning is used as supplementary to face-to-face learning. Therefore, students and teachers used to see each other face-toface and the nature of interaction did not appear as a real problem. The sudden shift to fully online courses made a lot of instructors and learners complain about the lack of interaction (Vellanki, \& Bandu, 2021; Benadla, \& Hadji, 2021; Wut \& Xu, 2021; Itmeizeh, \& Farrah, 2021; Zboun, \& Farrah, 2021; Dhawan, 2020; Farrah \& Al-Bakri, 2020). This study aims to identify some reasons behind students' lack of interaction in online learning environment. Moreover, it is hoped that the results of this study will provide teachers and instructors with some useful ideas and suggestion that may help them to enhance and promote their students interaction and participation during the online classes.

\section{Literature Review}

This section aims to review some studies that have been conducted about the nature of interaction in the online environment. Several studies discussed the importance of maintaining effective interaction in the online classroom.

Murray, Pérez, Geist, and Hedrick (2012) explored how student- content interaction effects the students' engagement and learning. They found that student-content interaction is the principal mode of interaction in the online learning environment as they also found that there is a strong relationship between the student's interaction with the content and the student's success. students interaction is measured by their access for resources, so the more resources students interacts with, the greater chance for them to get higher level of successfulness in the online course.

Similarly, Abrami, Bernard, Bures, Borokhovski, and Tamim (2010) explored the importance on the three types of interaction further using principles and applications stemming from self-regulation and multimedia learning theories, research-based motivational principles and collaborative learning principles.

York and Richardson (2012) explored the factors that increase interaction according to the perceptions of six experienced instructors of online learning. They found three types of factors that influence interaction in online learning which are: course structure factors such as group work, course environment, activities, and so on, feedback factors that includes feedback and assessing discussion questions, and discourse techniques and facilitation factors that include immediacy behaviors, discourse guidelines, and so on.

Downing, Lam, Kwong, Downing, and Chan (2007) identified how students can create an online community by their own only if it promoted in an appropriate way by the structure of the course. Their study also identifies three phases of online interaction which are: phase one; the socially formative phase, phase two: the socially instrumental phase, and phase three: the withdrawal phase.

Song and McNary (2011) have examined students' interaction patterns. The findings of their study suggest implications for the taxonomy instrument and for online course design. The implications the study suggests are as the following:

- Course design vs students' interaction: suggests that there is a relationship between the course design and the students; interaction

- CLCST for Asynchronous Collaborative Learning Environments.

- Number of Posts vs. Students' Success: they found that there is no strong relationship between the students' number of posts and their success.

Linton (2013) discussed how online learning affects teachers and students' interaction according to his own experience in online learning as some of the courses that he took online lack in opportunities for interaction. He stated that these courses consisted of reading books the instructor posts for them and listening to the lectures. Students participate only in asynchronous discussion boards so he identified strategies to increase interaction and participation in online learning environment. There strategies are organized by the three types of interaction that Moore (1989) defined:

- Learner-instructor interaction

- Learner-content interaction

- Learner-learner interaction

He found that learner- instructor interaction is the most important type of interaction as the frequent interaction between instructor and student leads to better levels of students' engagement and aid them to feel great "sense of community" (Brinthaupt, Fisher, Gardner, Raffo, \& Woodard, 2011; Mayes et al., 2011). He also 
found that online students need more opportunities to interact with each other. It is more important for instructors to design quality interactions rather than numerous interactions.

\section{- Studies in the Arab world}

To the best knowledge of the researchers, a limited number of studies were conducted in the Arab world that addressed interaction in online learning during Covid 19 pandemic (Vellanki \& Bandu, 2021; Benadla \& Hadji, 2021; Ammour, K. (2021).

Benadla and Hadji (2021) examined how the University of Dr. MoulayTahar in Saida, Algeria, employed Moodle platform to facilitate the teaching process during the Covid 19. They stressed the issues of distance elearning that challenge both teachers and students alike. Among their major findings is that E. Learning was a complex process as due to the lack of teachers' the technical skills and experience. Moreover, they added that students held negative attitudes towards e-learning, and they would prefer face-to-face interaction in the classroom than virtual learning.

Similarly, Vellanki and Bandu (2021) discussed some of the projected challenges concerning the application of TBLT in online teaching and learning contexts in Oman and Suadi Arabia. They observed that the precipitous move to online teaching has drastically transformed our teaching practices as teachers moved to online teaching either fully or partially. They raised the issue that one of the key issues of online teaching is maintaining students' interest and keeping them engaged in the virtual classroom. They added that making students interact with each other and their teachers is one of the biggest challenges. They concluded that "teachers should use textbooks that offer some flexibility, modify materials to make the activities into suitable tasks and notice how learners use language with the available linguistic and non-linguistic resources" (p. 123).

Ammour (2021) explored Algerian teachers' challenges in EFL elementary reading classes during the Covid19 pandemic. He observed that the Covid-19 pandemic has brought some difficulties like learners' lack of cognitive focus and decreased motivation. According to his findings, the transform from face-to-face learning to online learning made the teaching process more challenging.

\section{Methodology}

In this section, the researchers describe the design of the study, the participants' characteristics, the instruments and the procedure of the study. Finally, they explain data analysis

\section{Design of the Study}

This is a descriptive study. The data for this study was collected through a questionnaire. To archive objectives of the study, the researchers employed a descriptive survey research design with a quantitative approach. This type of research helps to describe and interprets the current status of the issue under study (Charles 1998). According to Etikan et al. (2016), one of the advantages of the quantitative research is its ability to explain the phenomena and bring a better understanding. This section is divided into three parts which are the participant's part, the instrument parts, and the procedure part. This section aims at providing information about how this study was conducted and describes the study itself.

\section{- Participants:}

This study was conducted in 2020/2021. The participants of this study comprised one hundred students from the English Department at Hebron University, Hebron University, Palestine. The two researchers are from Hebron University and they have chosen their participants from Hebron University as it is easier to collect data during Covid 19 pandemic. The participants were chosen using the available sampling method. The questionnaire was posted for one week and the researchers decided to stop receiving responses when the number of the respondents reached $100.78 \%$ of the participants were females and $22 \%$ of them were males. The academic level of these students ranges from freshmen to seniors: freshmen (5\%), sophomores (18\%), juniors (26\%), and seniors (51\%).

Table (1): Students' Demographic Data

\begin{tabular}{llcc}
\hline Gender & Variables & Frequency & Percent \\
\cline { 2 - 4 } & Male & 22 & 22.0 \\
& Female & 78 & 78.0 \\
& Total & $\mathbf{1 0 0}$ & $\mathbf{1 0 0 . 0}$ \\
\hline Academic level & Freshman & 5 & 5.0 \\
& Sophomore & 18 & 18.0 \\
& Junior & 26 & 26.0 \\
& Senior & 51 & 51.0 \\
& Total & $\mathbf{1 0 0}$ & $\mathbf{1 0 0 . 0}$ \\
\hline
\end{tabular}

\section{- Instrument:}

This study employed a survey-questionnaire to collect data to probe English language students' perceptions of the reasons behind lack of interaction in the online environment and suggesting some ideas that may promote interaction. The questionnaire was developed by the researchers via using the literature review which was conducted to determine the issues related to interaction in the online classroom. After the literature review, a $23-$ item questionnaire was developed by the researchers. The participants were asked to respond to a 23 item questionnaire on Likert scale (strongly agree, agree, neutral, disagree, and strongly disagree) posted online 
through a Google format likert scale questionnaire. In addition to the demographic data section, the questionnaire is divided into two major sections. The first section has items that are related to reasons behind lack of interaction and the second section has some items related to promoting interaction in the online environment.

\section{- Procedure:}

Due to COVID-19 pandemic and quarantine, the questionnaire was shared with English major students via the social platforms such as Facebook, Messenger, and Gmail. The questionnaire was posted on English major students at Hebron university group as well as it was shared with English major students groups in messenger application. The supervisor of this study also shared the questionnaire with English major students via Gmail and the students were asked to fill out the questionnaire. After collecting the quantitative data, they were analyzed statistically using SPSS version 24.

\section{Validity and Reliability of the questionnaire}

To confirm validity, the first draft of the questionnaire was carefully examined by the two researchers. Then, it was given to an expert from the Faculty of Education at Hebron University to check it for content and relevance. He suggested some modifications and deleting certain items resulting final version of the questionnaire. The reliability coefficient of the questionnaire was tabulated. The overall Cronbach's Alpha coefficient was 0.95, indicating a very high internal reliability for the instrument as a research tool (See Appendix).

\section{Results}

This section contains the results of the collected data from the questionnaire's responses. First, we present the findings related to the first research question.

"What are the reasons behind students' lack of interaction during online courses?"

As table two reveals, there are a number of factors behind lack of interaction:

Table (2): Means of the factors that contribute to less interaction

\begin{tabular}{|c|c|c|c|}
\hline No & Item & Mean & Std. Deviation \\
\hline 8 & Some students may get bored and fall asleep during online classes & 3.83 & 1.400 \\
\hline 9 & The quality of internet connection affects students' and instructor's interaction & 3.80 & 1.449 \\
\hline 2 & $\begin{array}{l}\text { The lack of computers and technological skills have an effect on students and teacher's } \\
\text { interaction }\end{array}$ & 3.73 & 1.332 \\
\hline 7 & $\begin{array}{l}\text { Some students do not interact in the online courses because they do not take them } \\
\text { seriously }\end{array}$ & 3.67 & 1.319 \\
\hline 3 & Some students feel shy to interact in online courses & 3.61 & 1.331 \\
\hline 10 & $\begin{array}{l}\text { Some students make false excuses to avoid attending courses and interacting during } \\
\text { courses (such as the bad internet connection excuse or that there is noise around them so } \\
\text { they can't speak and interact) }\end{array}$ & 3.58 & 1.379 \\
\hline 4 & Instructors can affect student's interaction & 3.55 & 1.333 \\
\hline 6 & Some instructors do not have enough experience in teaching online courses & 3.54 & 1.403 \\
\hline 1 & Interaction in the online learning environment has been reduced and affected & 3.46 & 1.298 \\
\hline 5 & Instructors sometimes prevent students from interaction during online courses & 2.95 & 1.351 \\
\hline
\end{tabular}

Table (2) shows the means of items for the reasons behind lack of interaction. The means are ordered from the highest means to the lowest ones. It shows that most of the students agree with the suggested reasons about why students do not interact in the online courses. The highest mean is for item $8(\mathrm{M}=3.83)$ which means that most students agree and strongly agree that some students may get bored and fall asleep during online classes. This is followed by Items $9(\mathrm{M}=3.80)$ The quality of internet connection affects students' and instructor's interaction and $2(\mathrm{M}=3.73)$. Both items talk about slow internet connection and the lack of computers and technological skills as factors that have an effect on students and teacher's interaction. Other items that most of students tended to agree with are items $7(\mathrm{M}=3.73)$ some students do not interact in the online courses because they do not take them seriously and $3(\mathrm{M}=3.61)$ some students feel shy to interact in online courses. This is followed by item $10(\mathrm{M}=3.58)$ some students make false excuses to avoid attending courses and interacting during courses (such as the bad internet connection excuse or that there is noise around them so they can't speak and interact). Other items that got moderate to high agreement with are items $4(M=3.55)$ Instructors can affect students' interaction and $6(M=3.54)$ some instructors do not have enough experience in teaching online courses. The lowest mean is for item $5(\mathrm{M}=2.2)$ that instructors sometimes prevent students from interaction during online course.

The second research Question:

How can we enhance students' interaction during online courses?

Table three reveals some ideas and suggestions to promote interaction 
Table (3): Means of section two ideas and suggestions to promote interaction

\begin{tabular}{|c|c|c|c|}
\hline No & Item & Mean & Std. Deviation \\
\hline 16 & $\begin{array}{l}\text { Instructors can ask random questions during the class in order to make their students follow } \\
\text { up with them }\end{array}$ & 3.87 & 1.160 \\
\hline 20 & $\begin{array}{l}\text { Instructors can encourage students to participate by giving them extra marks if they } \\
\text { participated }\end{array}$ & 3.8000 & 1.31041 \\
\hline 11 & $\begin{array}{l}\text { Instructors can use share screen strategy to attract students' attention and make students } \\
\text { interact more with them and with the content }\end{array}$ & 3.76 & 1.304 \\
\hline 22 & $\begin{array}{l}\text { Instructors can pose extra questions during the class to encourage their students to interact } \\
\text { during the class }\end{array}$ & 3.7300 & 1.26215 \\
\hline 17 & $\begin{array}{l}\text { Instructors can ask students to click on raise hand button to see who is following up and who } \\
\text { is not }\end{array}$ & 3.7100 & 1.17461 \\
\hline 23 & $\begin{array}{l}\text { Instructors can post the upcoming material for the next class to encourage students to be } \\
\text { well prepared and fully interacting during the class }\end{array}$ & 3.6700 & 1.23137 \\
\hline 14 & $\begin{array}{l}\text { Instructors can play videos related to the course materials and content during the class to } \\
\text { make the lecture more entertaining }\end{array}$ & 3.58 & 1.327 \\
\hline 13 & $\begin{array}{l}\text { Instructors can use power point to project the course materials in order to grab their } \\
\text { student's attention and make them interact more }\end{array}$ & 3.51 & 1.299 \\
\hline 21 & Instructors can make in-class writing assignments in order to keep their students active & 3.4600 & 1.35900 \\
\hline 15 & $\begin{array}{l}\text { Instructors can use games related to the course to make their students participate and } \\
\text { interact more }\end{array}$ & 3.34 & 1.356 \\
\hline 12 & $\begin{array}{l}\text { Instructors can ask their students to share their screen randomly to see their work and make } \\
\text { them tuned }\end{array}$ & 3.19 & 1.426 \\
\hline 19 & $\begin{array}{l}\text { Instructors can make pop quizzes in the middle of their classes so they make sure that the } \\
\text { students are following up and tuned }\end{array}$ & 3.0800 & 1.44725 \\
\hline 18 & $\begin{array}{l}\text { Instructors can make no recordings for their lectures and classes to encourage students to } \\
\text { attend their lectures and participate more }\end{array}$ & 2.6800 & 1.51677 \\
\hline
\end{tabular}

Table (3) shows the means of the suggested ideas about increasing and enhancing students' interaction in online learning environment. The data presented in Table 3 indicates that majority of the participants agreed with the items regarding some of the factors that may promote online interaction. It shows that most students agree upon the suggested ideas. The highest mean is for item $16(\mathrm{M}=3.87)$ which is Instructors can ask random questions during the class in order to make their students follow up with them. This is followed by item 20 $(\mathrm{M}=3.80)$ Instructors can encourage students to participate by giving them extra marks if they participated. Then item $11(\mathrm{M}=3.76)$ Instructors can use share screen strategy to attract students' attention and make students interact more with them and with the content. This is followed by item22 (M=3.73) Instructors can pose extra questions during the class to encourage their students to interact during the class. Then comes item $17(\mathrm{M}=3.71)$ Instructors can ask students to click on raise hand button to see who is following up and who is not. This is followed by item $23(\mathrm{M}=367)$ Instructors can post the upcoming material for the next class to encourage students to be well prepared and fully interacting during the class. Other items like 13, 14, and 21 got moderate agreement: Instructors can play videos related to the course materials and content during the class to make the lecture more entertaining Instructors can use power point to project the course materials in order to grab their students'attention and make them interact more

Instructors can make in-class writing assignments in order to keep their students active

The lowest mean is for item $18(\mathrm{M}=2.68)$ that is Instructors can make no recordings for their lectures and classes to encourage students to attend their lectures and participate more.

\section{Discussion}

According to the study results of section one, interaction and participation in online learning has been effected negatively and students tend to avoid interaction during online courses for many different reasons that I will explain latter on. According to Linton (2013) in most online and virtual courses and class students do not interact and participate as they don't find the appropriate opportunities to interact in these classes. Depending on the study conducted, the reasons behind the low interaction levels in online learning at Hebron University are the following:

- Some students do not interact in the online courses because they do not take them seriously. The results of the questionnaire showed that most students do not interact during the online classes and courses because they do not take them seriously, so they avoid attending lectures, ignore attending, do not interact. The reason behind this may be because they are not used to this kind of learning that is via social platforms or because they feel that they are free at their homes and no one can see them, so they do not take them seriously because there are no strict roles in online learning as face-to-face learning

- The quality of internet connection affects students' and instructor's interaction. A number of students agreed that the quality of internet connection affects their interaction such as the bad internet connection that does 
not allow them to interact and attend all of their lectures as the connection is slow and bad in their region. This finding is compatible with Husniyah (2018) results that the poor internet access is a major concern in online and blended learning.

- Some students make false excuses to avoid attending courses and interacting during courses (such as the bad internet connection excuse or that there is noise around them so they can't speak and interact). The results shows that students make false excuses to avoid interacting during their online sessions and fool their instructors. So that, instructors and teachers should be aware of this point.

- Instructors can affect student's interaction. According to the results, some students agree that instructors influence their student's interaction and participation during the online courses. There is a significant relationship between teacher-student interaction and motivation (Akhtar et al., 2019).

- Some students may get bored and fall asleep during online classes.it seems that some students feel board during the online session because they are at their houses setting, so they get bored and fall asleep. In my point of view as a student and researcher, the early online sessions affect students' interaction as they feel sleepy and watch the lecture in their beds, so they may fall asleep during their lectures.

According to my results, most of the students do not agree that shyness is one of the reasons that affect their interaction and they also do not consider the lack of computers and technological skills a reason for them to not interact. This finding is at variance with OECD (2015) that computer and technological skills are important in the learning process and making students more active. Most of the participants do not agree that instructors do not have enough experience or they are not qualified enough to teach online courses as they mostly disagree that instructors prevent students from interacting during the online sessions.

The results of section two which mainly about the ideas and the suggestion instructors may use in order to increase their students interaction in online session were as the following:

- Instructors can ask random questions during the class in order to make their students follow up with them. Most of the students agrees with that suggestion that instructors can ask their students random question during the online classes in order to make their students following up. This finding is compatible with Ragawanti (2009) finding that students prefer the random nomination questions because it makes the students more attentive.

- Instructors can ask students to click on raise hand button to see who is following up and who is not. In accordance with the study results, most of the participants agree with raise hand technique. The advantage of this technique is that it makes the students tuned and following up with their instructors along with that, it is easy.

- Instructors can encourage students to participate by giving them extra marks if they participated. Most of the students and the participants consider the extra marks and grades effective technique instructors can use to increase their interaction because it motivates almost all of the students. This finding agrees with Docan (2006) that grades and extra marks work as motivators to students' interaction and engagement in the learning process.

- Instructors can use power point to project the course materials in order to grab their students' attention and make them interact more. Using power point as a technique in paying students attention during online courses is considered and effective one by most of the participants. Projecting the course materials content in power point makes it easy and more entertaining for students than the ordinary teaching using books and the content of the course material which compatible with Hashemi et al. (2011) that power point is an effective tool for teaching and learning in classes.

- Instructors can use games related to the course to make their students participate and interact more. Some of the students are with using games during the online sessions to make the lectures more entertaining such as using words and vocabulary games.

- Instructors can make in-class writing assignments in order to make their student active and make bonus question during the class. Instructors can use this technique by posting assignments with marks during the lecture about the lecture subject in order to make their students following up all over the class to answer that assignment.

According to the results, the rest techniques are not preferable by most of the participants such as the share screen strategy between the students and the instructors, pop quizzes and finally no recording technique that almost all the participants disagreed with.

\section{Conclusion}

Most of the students avoid interacting during online courses because they actually do not take them seriously as the quality of the internet also affects their interaction negatively. They also make false excuses to avoid interacting during the online sessions such as the bad internet connection excuses. Instructors and teachers also can affect students' interaction negatively and reduce their interaction and participation levels.

Along with these reasons, the study suggested some useful ideas that teachers and instructors can use with their students to make them more active and increase their participation. The suggestion are: asking random questions during the class, using raise hand technique, giving extra marks and grades, using power point in 
presentations during the classes, playing games related to the course content, and finally making in class writing assignments.

\section{Limitation's recommendation of the study:}

This study was limited to English major students at Hebron University including the four majors: English Literature, English- French, Teaching Methods of English Language, and English translation. It is also limited because it is conducted during COVID-19 Pandemic and the questionnaire is shared via social platforms only such as Facebook, Messenger, and Gmail.

Teachers and instructors should be more aware in giving the online courses as students sometimes make false excuses and they have to ask their students why they did not interact and listen to their own suggestions and ideas and if there is any kind of problem, instructors should resolve it as soon as possible.

As interaction in online learning environment is a problem, most instructors suffer from, other studies can be conducted to suggest more ideas and techniques instructors and teachers can use to improve their students interaction levels.

Since there are many different reasons why students do not interact in online learning courses, other studies can track exactly what these reasons are and provide some effective and useful ideas that can help students to interact more in the online learning environment.

\section{References}

1. Abrami, P. C., Bernard, R. M., Bures, E. M., Borokhovski, E., \& Tamim, R. (2010). Interaction in distance education and online learning: Using evidence and theory to improve practice. Journal of Computing in Higher Education, 23: 82-103, DOI:10.1007/s12528-011-9043-x.

2. Ahmad, C. N. C., Shaharim, S. A. \& Abdullah, M. F. N. L. (2017). Teacher-student interactions, learning commitment, learning environment and their relationship with student learning comfort. Journal of TURKISH SCIENCE EDUCATION, 14(1), 57-72. DOI:10.12973/tused.10190a.

3. Akhtar, Sh., Hussain, M., Azfal, M., \& Gilani, S. A. (2019). The Impact of Teacher-Student Interaction on Student Motivation and Achievement. EUROPEAN ACADEMIC RESEARCH, 7(2): 1202-1222.

4. Ammour, K. (2021). Developing Elementary EFL Learners' Procedural Knowledge and Strategic Awareness in Reading Classes during the Covid-19 Pandemic: Algerian Teachers 'Challenges. Arab World English Journal (AWEJ) Special Issue on Covid 19 Challenges, (1): 127- 135. https://dx.doi.org/10.24093/awej/covid.9.

5. Baber, H. (2021). Social interaction and effectiveness of the online learning - A moderating role of maintaining social distance during the pandemic COVID-19. Asian Education and Development Studies, ahead-to- print, D0I:10.1108/AEDS09-2020-0209.

6. Benadla, D., \& Hadji, M. (2021). EFL students' affective attitudes towards distance e-learning based on Moodle platform during the covid-19the pandemic: perspectives from Dr. MoulayTahar University of Saida, Algeria. Arab World English Journal (AWEJ) Special Issue on Covid 19 Challenges, (1): 55-67. https://dx.doi.org/10.24093/awej/covid.4.

7. Brinthaupt, T. M., Fisher, L. S., Gardner, J. G., Raffo, D. M., \& Woodard, J. B. (2011). What the best online teachers should do. Journal of Online Learning and Teaching, 7(4): 515-524.

8. Castaneda, D. \& Rentz, S. (2020). The power of discussion: Activating learning online (And in Person). Retrieved from https://elearningindustry.com/social-interaction-in-online-courses-discussion-activating-learning.

9. Charles, C. M. (1998). Introduction to Educational Research. Springfield, MA: Addison Wesley Longman.

10. Coman, C., Țîru L. G., Meseșan-Schmitz, L., Stanciu, C., \& Bularca, M. C. (2020). Online teaching and learning in higher education during the coronavirus pandemic: students' perspective. Sustainability, MDPI, Open Access Journal, 12(24): 124, https://doi.org/10.3390/su122410367.

11. Dhawan, S. (2020). Online learning: A panacea in the time of COVID-19 crisis. Journal of Educational Technology Systems, 49(1) 5-22

12. DeWitt, P. (2020). 6 reasons students aren't showing up for virtual learning. Retrieved from https://www.edweek.org/leadership/opinion-6-reasons-students-arent-showing-up-for-virtual-learning/2020/04

13. Docan, T. N. (2006). Positive and negative incentives in the classroom: An analysis of grading systems and student motivation. Journal of Scholarship of Teaching and Learning, 6(2): 21-40, Retrieved from https://files.eric.ed.gov/fulltext/E]854925.pdf.

14. Downing, K. J., Lam, T., Kwong, T., Downing, W., \& Chan, S. (2007). Creating interaction in online learning: a case study, ALT-J, 15(3): 201-215. DOI: 10.1080/09687760701673592.

15. Etikan, Ilker, Abubakar, Sulaiman Musa, and Alkassim, Rukayya Sunusi. (2016). Comparison of convenience sampling and purposive sampling. American Journal of Theoretical and Applied Statistics. 5(1): 1-4. doi: 10.11648/j.ajtas.20160501.11.

16. Evans, J. (2010). Enhancing Online Learning Using the Three Types of Interaction. Retrieved from https://digitallearningacademy.org/enhancing-online-learning-using-the-three-types-of-interaction/

17. Farrah. (2006). An Evaluation of an online English for academic writing program using the IHEP 2000 quality benchmarks. Unpublished Ph. D Dissertation, International Islamic University: Malaysia. 
18. Farrah, M. \& Al-Bakry, G. H. (2020). Online learning for EFL students in Palestinian universities during corona pandemic: Advantages, challenges and solutions. Indonesian Journal of Learning and Instruction, 3(2): 65-78.

19. Hashemi, M., Azizinezhad, M., \& Farokhi, M. (2011). Power Point as an innovative tool for teaching and learning in modern classes, Procedia - Social and Behavioral Sciences, 3(1): 559-563. DOI: 10.1016/j.sbspro.2011.12.103.

20. Ho, Mei Lin C. (2004). Computer-Mediated Communication: Practice, Projects and Purposes. Teaching English with Technology. A Journal for Teachers of English. 4: 1-11

21. Husniyah, A. (2018). Blended learning in EFL classrooms with slow internet: insights from teachers and students. The Fourth International Conference on English Across Cultures, 68-79

22. Kearsley, G. (2000). Online education: Learning and teaching in cyberspace .Belmont, CA: Wadsworth.

23. Kelsey, K., D. \& D'souza, A., K. (2004). Student Motivation for Learning at a Distance: Does Interaction Matter? Online Journal of Distance Learning Administration. Retrieved May 20, 2021 http://www.westga.edu/\%7Edistance/ojdla/summer72/kelsey72.html.

24. Krause, K., Bochner, S., \& Duchesne, S. (2006). Educational psychology for learning and teaching (2nd ed.). Southbank, Victoria: Nelson Australia Pty Ltd.

25. Li, S. Lalani, F. (2020). The COVID-19 pandemic has changed education forever. This is how. Retrieved from the rise of online learning during the COVID-19 pandemic | World Economic Forum (weforum.org)

26. Linton, J. (2013). Increasing interaction in online learning environments. Tech Tips for Teachers Blog. Retrieved from https://dcs.rutgers.edu/sites/default/files/pdf/increasing-interaction-in-online-learning-environments.pdf

27. Little, V. S. (2000). Design, Implementation and Assessment of an Online Writing Programme for Multi-age Students, Grades 9-12. Unpublished PhD thesis. California Institute of Integral Studies.

28. Moore, M. (1989). Three types of interaction. The American Journal of Distance Education, 3(2): 1-6. DOI:10.1080/08923648909526659.

29. Murray, M., Perez, J., Giest, D., Hedrick, A. (2012). Students' interaction with online course content: build it and they might come. Journal of Information Technology Education: Research, 11(1), D0I:10.28945/1592.

30. Itmeizeh, M. \& Farrah, M. (2021). EFL instructors and learners' perceptions towards utilization of online applications at Palestine Ahliya University and Hebron University. Universal Journal of Educational Research, 8(8), 3310 -3322. DOI: 10.13189/ujer.2021.0x0x0x

31. OECD (2015), Students, Computers and Learning: Making the Connection, PISA, OECD Publishing. https://doi.org/10.1787/9789264239555-en.

32. Phipps R. A. \& Merisotis, J., P. (2000). Quality on the line: Benchmarks for success in internet-based distance education. Institute for Higher Education Policy,Washington, D.C. Retrieved May 25, 2021, http://www.ihep.com/quality.pd.

33. Ragawanti, D. T. (2009). Questions and questioning techniques: A view of Indonesian students' preferences. DOI: 10.9744/kata.11.2.155-170.

34. Reformed Teaching Observation Protocol. (2011). Classroom Observation Project. Student-Student Classroom Interaction. Retrieved from https://serc.carleton.edu/NAGTWorkshops/certop/imp ssi.html.

35. Richards, J., \& Rodgers, T. (2004). Approaches and methods in language teaching. Cambridge: Cambridge University Press.

36. Song, L. \& McNary, S. W. (2011). Understanding students' online interaction: analysis of discussion board postings. Journal of Interactive Online Learning, 10(1). Retrieved from Understanding Students' Online Interaction: Analysis of Discussion Board Postings (ncolr.org)

37. Wut, Tm. \& Xu, J. (2021). Person-to-person interactions in online classroom settings under the impact of COVID-19: a social presence theory perspective. Asia Pacific Educ. Rev. https://doi.org/10.1007/s12564-021-09673-1.

38. Vellanki, S. S., \& Bandu, S. (2021). Engaging students online with technology-mediated task-based language teaching. Arab World English Journal (AWEJ) Special Issue on Covid 19 Challenges, (1)107 $126 . \quad$ DOI: https://dx.doi.org/10.24093/awej/covid.8.

39. Vrasidas, C. (2000). Constructivism versus objectivism: Implications for interaction, course design, and evaluation in distance education. International Journal of Educational Telecommunications, 6: 339-362

40. York, C., \& Richardson, J. C. (2012). Interpersonal interaction in online learning: Experienced online instructors' perceptions of influencing factors. Journal of Asynchronous Learning Network, 16(4): 83-98.

41. Zboun, J.S. \& Farrah, M. (2021). Students' perspectives of online language learning during corona pandemic: Benefits and challenges. Indonesian EFL Journal, 7(1), 13-20. 


\section{Appendix: Questionnaire}

Dear students: The researchers aim to conduct a research entitled "Interaction in Online Learning Environment during Covid -19: Factors behind Lack of Interaction and Ideas for promoting it ". This research aims to identify the factors behind lack of interaction at Hebron University. Moreover, it aims to explore some suggestions for promoting interaction in the online learning classroom. You are kindly requested to provide sincere opinion or response to the questions. Your answers will be treated with confidentiality.

\section{PART I}

Please, tick $(\checkmark)$ the appropriate box.

\begin{tabular}{|ll}
\hline $\begin{array}{l}\text { A. Gender } \\
\text { Female }\end{array}$ & Male \\
\hline $\begin{array}{l}\text { B- Academic Level } \\
\text { Freshman Sophomore Junior Senior }\end{array}$
\end{tabular}

\section{PART II}

Indicate the extent to which you agree or disagree with the following statements regarding interaction in the online environment by putting a cross in the appropriate box using the scale given below.

1 Strongly Disagree

2 Disagree

3 Neutral

4 Agree

5 Strongly Agree

\begin{tabular}{|c|c|c|c|c|c|c|}
\hline No. & Reasons behind of lack of interaction & 1 & 1 & 3 & 4 & 5 \\
\hline 1. & Interaction in the online learning environment has been reduced and affected & & & & & \\
\hline 2. & $\begin{array}{l}\text { The lack of computers and technological skills have an effect on students and } \\
\text { teacher's interaction }\end{array}$ & & & & & \\
\hline 3. & Some students feel shy to interact in online courses & & & & & \\
\hline 4. & Instructors can affect student's interaction & & & & & \\
\hline 5. & Instructors sometimes prevent students from interaction during online courses & & & & & \\
\hline 6. & Some instructors do not have enough experience in teaching online courses & & & & & \\
\hline 7. & $\begin{array}{l}\text { Some students do not interact in the online courses because they do not take them } \\
\text { seriously }\end{array}$ & & & & & \\
\hline 8. & Some students may get bored and fall asleep during online classes & & & & & \\
\hline 9 & The quality of internet connection affects students' and instructor's interaction & & & & & \\
\hline 10 & $\begin{array}{l}\text { Some students make false excuses to avoid attending courses and interacting during } \\
\text { courses (such as the bad internet connection excuse or that there is noise around } \\
\text { them so they can't speak and interact) }\end{array}$ & & & & & \\
\hline \multicolumn{7}{|c|}{ Suggestions for promoting interaction } \\
\hline 11 & $\begin{array}{l}\text { Instructors can use share screen strategy to pay students attention and make } \\
\text { students interact more with them and with the content }\end{array}$ & & & & & \\
\hline 12 & $\begin{array}{l}\text { Instructors can ask their students to share their screen randomly to see their work } \\
\text { and make them tuned }\end{array}$ & & & & & \\
\hline 13 & $\begin{array}{l}\text { Instructors can use power point to project the course materials in order to grab their } \\
\text { student's attention and make them interact more }\end{array}$ & & & & & \\
\hline 14 & $\begin{array}{l}\text { Instructors can play videos related to the course materials and content during the } \\
\text { class to make the lecture more entertaining }\end{array}$ & & & & & \\
\hline 15 & $\begin{array}{l}\text { Instructors can use games related to the course to make their students participate } \\
\text { and interact more }\end{array}$ & & & & & \\
\hline 16 & $\begin{array}{l}\text { Instructors can ask random questions during the class in order to make their students } \\
\text { follow up with them }\end{array}$ & & & & & \\
\hline 17 & $\begin{array}{l}\text { Instructors can ask students to click on raise hand button to see who is following up } \\
\text { and who is not }\end{array}$ & & & & & \\
\hline 18 & $\begin{array}{l}\text { Instructors can make no recordings for their lectures and classes to encourage } \\
\text { students to attend their lectures and participate more }\end{array}$ & & & & & \\
\hline 19 & $\begin{array}{l}\text { Instructors can make pop quizzes in the middle of their classes so they make sure that } \\
\text { the students are following up and tuned }\end{array}$ & & & & & \\
\hline 20 & $\begin{array}{l}\text { Instructors can encourage students to participate by giving them extra marks if they } \\
\text { participated }\end{array}$ & & & & & \\
\hline 21 & $\begin{array}{l}\text { Instructors can make in-class writing assignments in order to make their student } \\
\text { active }\end{array}$ & & & & & \\
\hline 22 & $\begin{array}{l}\text { Instructors can make bonus questions during the class to encourage their students to } \\
\text { interact during the class }\end{array}$ & & & & & \\
\hline 23 & $\begin{array}{l}\text { Instructors can post the upcoming material for the next class to encourage students to } \\
\text { be well prepared and fully interacting during the class }\end{array}$ & & & & & \\
\hline
\end{tabular}

